\title{
The Significance of the Adaptive Thermal Comfort Practice over the Structure Retrofits to Sustain Indoor Thermal Comfort
}

\author{
Aiman Albatayneh ${ }^{1}$, Mustafa Jaradat ${ }^{1}$ D, Mhd Bashar AlKhatib ${ }^{1}$, Ramez Abdallah ${ }^{2}$ (D) Adel Juaidi ${ }^{2, *(D)}$ \\ and Francisco Manzano-Agugliaro ${ }^{3, *}$ (D)
}

1 School of Natural Resources Engineering and Management, German Jordanian University, P.O. Box 35247, Amman 11180, Jordan; Aiman.Albatayneh@gju.edu.jo (A.A.); mustafa.jaradat@gju.edu.jo (M.J.); basharkhatteeb@gmail.com (M.B.A.)

2 Mechanical \& Mechatronics Engineering Department, Faculty of Engineering \& Information Technology, An-Najah National University, P.O. Box 7, Nablus 00970, Palestine; ramezkhaldi@najah.edu

3 Department of Engineering, ceiA3, University of Almeria, 04120 Almeria, Spain

* Correspondence: adel@najah.edu (A.J.); fmanzano@ual.es (F.M.-A.)

Citation: Albatayneh, A.; Jaradat, M.; AlKhatib, M.B.; Abdallah, R.; Juaidi, A.; Manzano-Agugliaro, F. The Significance of the Adaptive Thermal Comfort Practice over the Structure Retrofits to Sustain Indoor Thermal Comfort. Energies 2021, 14, 2946. https://doi.org/10.3390/en14102946

Academic Editor: Boris Igor Palella

Received: 26 March 2021

Accepted: 16 May 2021

Published: 19 May 2021

Publisher's Note: MDPI stays neutral with regard to jurisdictional claims in published maps and institutional affiliations.

Copyright: (c) 2021 by the authors. Licensee MDPI, Basel, Switzerland. This article is an open access article distributed under the terms and conditions of the Creative Commons Attribution (CC BY) license (https:// creativecommons.org/licenses/by/ $4.0 /)$.

\begin{abstract}
Any building's design should sustain thermal comfort for occupants and promote less energy usage during its lifetime using accurate building retrofits to convert existing buildings into lowenergy buildings so that the heating and cooling loads can be minimized. Regarding the methodology adopted in this research, an energy model of an educational building located at the German Jordanian University in Jordan was constructed utilizing DesignBuilder computer software. In addition, it was calibrated utilizing real energy consumption data for a 12-month simulation of energy performance. Subsequently, a computerized evaluation of the roles of building envelope retrofits or the adaptive thermal comfort limits in the reduction of the overall building energy consumption was analyzed. The results of the study show that the current building's external wall insulation, roof insulation, glazing, windows, and external shading devices are relatively energy-efficient but with high cost, resulting in significant financial losses, even though they achieved noticeable energy savings. For instance, equipping the building's ventilation system with an economizer culminated in the highest financial profit, contributing to an annual energy savings of $155 \mathrm{MWh}$. On the other hand, in an occupant-centered approach, applying the adaptive thermal comfort model in wider ranges by adding $1{ }^{\circ} \mathrm{C}, 2{ }^{\circ} \mathrm{C}$, and $3{ }^{\circ} \mathrm{C}$ to the existing operating temperatures would save a significant amount of energy with the least cost (while maintaining indoor thermal comfort), taking over any retrofit option. Using different adaptive thermal comfort scenarios $\left(1^{\circ} \mathrm{C}, 2{ }^{\circ} \mathrm{C}\right.$, and $\left.3{ }^{\circ} \mathrm{C}\right)$ led to significant savings of around $5 \%, 12 \%$, and $21 \%$, respectively. However, using different retrofits techniques proved to be costly, with minimum energy savings compared to the adaptive approach.
\end{abstract}

Keywords: adaptive thermal comfort; energy saving; built environment; building retrofits

\section{Introduction}

An increasing awareness of the relationship between energy use, economic growth, and the equivalent environmental pollutants has been raised due to the threat posed by global warming and climate change. Due to the growing concerns over these issues, numerous studies have reviewed thermal comfort research work and discussed the implications for building energy efficiency, with some works summarized by the authors of [1].

The design and construction of building envelopes are carried out around the world to improve the energy efficiency of buildings. The building envelopes' design and construction include thermal insulation; technical and economic analysis of energy-efficient measures for the renovation of existing buildings; reflective coatings; the control of heating, ventilation, and air-conditioning (HVAC) installations; and lighting systems [1].

Jordan faces a massive influx of refugees, leading to increased energy consumption. Energy consumption in the Jordanian educational sector includes public and private 
universities, colleges, and public and private schools. Energy consumption by this sector amounts to about $3.2 \times 10^{8} \mathrm{kWh}$ or $14 \%$ of the total consumption of different sources of energy by the service sector, while the amount of energy consumed by universities, colleges, and schools amounts to $1.7 \times 10^{8} \mathrm{kWh}, 0.1 \times 10^{8} \mathrm{kWh}$, and $1.45 \times 10^{8} \mathrm{kWh}$, respectively [2]. In turn, universities, colleges, and schools account for $52 \%, 3 \%$, and $45 \%$, respectively, of the total consumption of different forms of energy by the educational sector [3].

An appropriate thermal comfort level must be developed for low-energy buildings for the purpose of precisely estimating the heating and cooling energy needed to maintain thermal comfort within a building. The precision offered by the thermal comfort model is believed to be advantageous as it provides cost savings and leads to a reduction in the overconsumption of energy [4]. The accurate thermal comfort design and functioning of structures as well as heating, ventilation, and air-conditioning (HVAC) systems must consider all the relevant factors. Standards are frequently overlooked or erroneously applied in the building design process. Design input values are generally perceived to be widespread values instead of recommended values that should be utilized under precise conditions. At operational levels, a limited number of variables are considered, with varying effects on thermal comfort calculations [5].

\subsection{Thermal Comfort}

Thermal comfort is defined by the psychological expression "condition of mind." The comfort levels of building residents in all situations can fluctuate and evolve over time due to psychological aspects. The manner in which a person perceives thermal comfort can be impacted by their memories of previous experiences. Thermal comfort refers to people's experience of the thermal conditions, and it is grounded on the thermal sensation of the occupant [6]. Adaptation occurs where experiences within a particular setting moderate future expectations. This is a critical factor for comprehending the discrepancy between results from the field and estimated theoretical/design forecasts for free-run mode buildings [7]. Strenuous work in hot, humid conditions represents a significant risk in health and economic terms for many laborers and their families in tropical regions when they are required to function outside their thermal comfort limits [8]. Seven buildings with air-conditioning located in South Korea were utilized to evaluate the impact that the residents' control over their environment had on the energy consumed for cooling. The results indicated that if the residents can control their thermal environment, this could lead to a reduction of up to $10 \%$ in thermal energy consumption, with no impact on the thermal comfort of the residents [9].

Factoring of the thermal comfort of occupants is performed based on measurements of the comfort zone of a specific value for the inhabitant. The American Society of Heating, Refrigerating, and Air-Conditioning Engineers (ASHRAE) developed thermal environmental conditions for human occupants which are used for categorizing the mix of individual factors and indoor thermal environments that create the thermal environmental conditions that are acceptable for most of the inhabitants. Thermal Environmental Conditions for Human Occupancy/ASHRAE Standard 55-2020 was established by the ASHRAE. The standard describes the categorization of the mix of indoor thermal environments and their individual factors, thus forming environmental environments that are acceptable to the majority of the population [10].

ASHRAE Standard 55-2020 uses two primary thermal comfort modules:

- $\quad$ The predicted mean vote (PMV) and the predicted percentage dissatisfied (PPD) models, which the International Standardisation Organisation (ISO) and Comité European de Normalisation (CEN) standards have also adopted [11].

- Adaptive thermal comfort models.

Standard BS EN 16798-1 and the same process is used for calculating the comfort temperature (the equations are similar, but the coefficients are not the same). Due to the lack of such a standard in Australia, ASHRAE 55 has been adopted [12]. 
The PMV is grounded on the principles of heat balance as well as data obtained within a climate-controlled environment under normal conditions. The PMV estimates the mean response of the public, similar to the ASHRAE thermal sensation scale. It should be noted that a satisfactory range of thermal comfort for PMV according to ASHRAE 55-2020 is from -0.85 to +0.85 , which equates to $20 \%$ PPD [10]. PMV thermal comfort is determined on the basis of six variables: Relative air velocity, air temperature, mean air humidity, mean radiant temperature, insulation of clothing, and metabolic rate [13]. There are positive and negative aspects of the PMV model. For instance, it can be challenging to make precise estimations of the PMV / PPD for clothing insulation and metabolic rates [14]. The PMV for thermal comfort also attempts to identify how inhabitants within the space respond with respect to the physics and physiology of heat transfer, which is a complicated process. It also considers the psychological factors that are critical in managing thermal comfort conditions. Multiple studies in the field have determined that it is challenging to utilize PMV in practicality as it can cause imprecision concerning the prediction of comfortable environments because it is dependent on the subjective perception and physiology of the respondents [15].

Currently, evaluating PMV thermal comfort conditions is possible using many software programs on the market. However, few of them reflect all six variables accountable for thermal comfort. This suggests that most software programs and apps for PMV index calculation must be used carefully and all specifications should be considered [16].

\subsection{Thermal Comfort and Energy Consumption}

Field research conducted in an office building with air-conditioning demonstrated that, in comparison with the PMV / PPD model with reduced energy usage, the thermal acceptance of inhabitants was enhanced by the adaptive model [17]. Research on multiple structures has shown that satisfactory internal conditions are frequently not achieved. This implies that the whole building sector must develop more accurate techniques to design and study indoor environments [18-20]. Numerous researchers have concentrated on assisting the operators of buildings with adapting their building and HVAC systems to meet the varied and complicated standards such that the building will become more energyefficient and the environmental quality of indoor spaces will be improved [5]. Due to the abovementioned complexities, the adaptive thermal comfort model was proposed to assist designers with determining acceptable indoor air temperatures for free-run buildings. It is important to note that the adaptive thermal comfort model is only applicable to free-run buildings and not those with air-conditioning, while the opposite is true for PMV/PPV [21].

The development of the adaptive module was based on several different experimental and empirical studies. The calculation of the indoor air temperature can be effectively performed by considering different factors, including how the occupants interact with their environment, such as when choosing to wear different clothes, when windows are opened/closed, the usage of energy-efficient fans, water consumption, and whether shades are drawn. A major outcome of the adaptive theory is that individuals residing in warmer regions are more tolerant of warmer indoor temperatures than the residents of colder regions [22].

The comfort zone encompasses the neutrality/comfort line and denotes the maximum and minimum temperatures for comfort to be maintained. Acceptability limits of $80 \%$ and $90 \%$ denote a comfort zone with an optimal comfort temperature of $2-3{ }^{\circ} \mathrm{C}$ on both sides of the comfort line, which is regarded as a satisfactory limit. Where fans are present, an additional $2{ }^{\circ} \mathrm{C}$ can be added to each side for the purpose of calculating the value of the comfort zone for climate conditions that are extremely hot and dry. In the case of humid conditions, it is possible to add $1{ }^{\circ} \mathrm{C}$ so that the value of the comfort zone can be calculated for each side [23]. The range of temperatures determined equates to acceptability limits of $80 \%$ and $90 \%$ and could be as much as $30^{\circ} \mathrm{C}$ based on the ASHRAE 55-2017 Standard [24].

A specific advantage of the adaptive thermal comfort module is that humidity and air velocity are included for calculating the operative temperature. Nevertheless, studies have 
indicated that, for the effects of the aforementioned factors on the inhabitants' thermal comfort to be analyzed, it is necessary to consider data relating to the opening/closure of windows and doors, as well as whether fans are operating [25]. Field experiments were performed in 26 classrooms with air-conditioning and 10 with natural ventilation based on physical measurements and surveys. The outcomes revealed that thermal comfort is not significantly impacted by humidity [26].

The energy consumption of buildings with natural ventilation is under half that of those with air-conditioning because the occupants can adapt to a broader range of temperatures that exceed the comfort zone described by the PMV model [27]. The model is also capable of predicting when inhabitants feel warmer than reality, which can promote excessive usage of air-conditioning [28].

The adaptive thermal comfort model (by the ASHRAE Standard 55-2020 and EN 16798-1) is employed for buildings with natural ventilation, whereas the PMV / PPD model can be implemented for buildings with air-conditioning, because the thermal comfort among the two is not accurately compared. The expectation factor, "e," was proposed by Fanger to determine the mean thermal sensation of occupants of a real building with no air-conditioning located in a warm region. This factor ranges from 0.5 to 1 , where buildings with air-conditioning have a value of 1 . However, for buildings with no air-conditioning, the expectancy factor is dependent on how long the warm weather lasts during the year, as well as whether a comparison can be made with buildings that do have air-conditioning in the area, and could range from 0.8 to 0.9 [28]. It is possible to lower mechanical temperature control if occupants are accepting of a wider range of indoor air temperatures, resulting in a reduction in energy consumption and operational costs, which therefore improves the environmental and economic performance of the building [29,30].

Occupants who have more personal control over the environment are generally more tolerant of a broader range of interior temperatures. In general, they tolerate a reduced operating temperature of $2.6^{\circ} \mathrm{C}$ and are less motivated to alter the existing conditions in comparison with occupants who cannot personally control the environment. It is advised that occupants interact with the thermal environment by opening/closing windows, using energy-efficient fans, and minimizing the utilization of controllable cooling and heating systems [31]. A case study conducted in the south of Spain focused on a high-tech tall building with good energy efficiency that saved occupation hours, resulting in a $28 \%$ reduction in the usage of air-conditioning as well as a considerable decrease in the general energy consumption [32].

This research attempts to investigate the significance of using the adaptive thermal comfort model as one of the energy retrofits strategies to save a significant amount of energy with the least cost instead of using costly retrofit techniques such as external wall insulation, roof insulation, glazing, windows, and external shading devices. The main aim of this study is to compare the roles of building envelope retrofits with the adaptive thermal comfort limits in the reduction of the overall building energy consumption by comparing the energy consumption of various types of buildings' envelope retrofits such as increasing the insulation layer of external walls and roof, replacing windows' glazing, and adding shading devices to wider ranges of adaptive thermal comfort temperature limits.

\section{Materials and Methods}

An energy model of an educational building located at the German Jordanian University in Jordan was constructed utilizing DesignBuilder computer software using real data recorded on the site.

\subsection{Location and the Building Characteristics}

The university building is located in Madaba province, which is around $35 \mathrm{~km}$ to the southwest of Amman, the capital city of the Hashemite Kingdom of Jordan, and is about $30 \mathrm{~km}$ to the northwest of Queen Alia International Airport. Madaba is situated in central Jordan and has a population of nearly 90,000 people. 
A hot and dry climate is characteristic of Jordan. In fact, summers are long, hot, and dry, whereas winters are short and cool. Jordan's location plays a part in this pattern of weather, as it is situated between the Arabian Desert and the eastern Mediterranean. The former is characterized by subtropical aridity, while the latter is characterized by subtropical humidity. January is the coldest month, with temperatures varying from $5{ }^{\circ} \mathrm{C}$ to $10^{\circ} \mathrm{C}$. In contrast, August is the hottest month, with temperatures varying from $20^{\circ} \mathrm{C}$ to $35^{\circ} \mathrm{C}$. The majority of days are sunny throughout the year in Jordan with an estimate of more than 300 days of sunshine. This is equivalent to a sunshine duration of about $3125 \mathrm{~h}$ /year [33]. In this analysis, we did not have hourly recorded weather data on the site for this specific period, so we used the hourly weather data built in the software's location library. The hourly weather data were utilized for carrying out the annual simulation.

The maximum temperatures were recorded in July and August, respectively. On the other hand, the minimum temperature was recorded in January. The highest velocity of wind was logged in February and March, whereas the lowest velocity of wind was logged in October. The university under discussion is a 5-story building occupying an area of $13,000 \mathrm{~m}^{2}$. The area of each floor is illustrated in Table 1. It is mainly comprised of classrooms, applied engineering science laboratories, and offices for faculty members and management workers, and their numbers on each floor are shown in Table 1. Moreover, there is an auditorium and a cafeteria, which are located on the first floor.

Table 1. Building's floor area and number of classrooms, offices, and laboratories on each floor of the building.

\begin{tabular}{ccccc}
\hline Floor Number & Area $\left(\mathbf{1 0}^{\mathbf{3}} \mathbf{m}^{\mathbf{2}}\right)$ & $\begin{array}{c}\text { Number of } \\
\text { Classrooms }\end{array}$ & $\begin{array}{c}\text { Number of } \\
\text { Offices }\end{array}$ & $\begin{array}{c}\text { Number of } \\
\text { Laboratories }\end{array}$ \\
\hline Ground Floor & 1.77 & 0 & 15 & 6 \\
\hline First Floor & 3.32 & 6 & 27 & 7 \\
\hline Second Floor & 2.62 & 10 & 21 & 6 \\
\hline Third Floor & 2.51 & 8 & 19 & 9 \\
\hline Fourth Floor & 2.49 & 0 & 25 & 15 \\
\hline
\end{tabular}

The building in question was modeled in 5 blocks. Each block resembles 1 story of the real building, as illustrated by Figure 1. The third and fourth floors have the same architectural design as the second floor.

In general, the building is operated 5 days a week (from Sunday to Thursday). However, it might be operated on Saturdays. Regarding the working hours, the building is operative $8 \mathrm{~h}$ per day (from 8 a.m. to 4 p.m.) for regular academic semesters (from October to July) and for $7 \mathrm{~h}$ for the summer semester (from July to September).

The materials used in each component of the building envelope and their corresponding thicknesses were acquired from the building's architectural design schematics (see Table 2). 


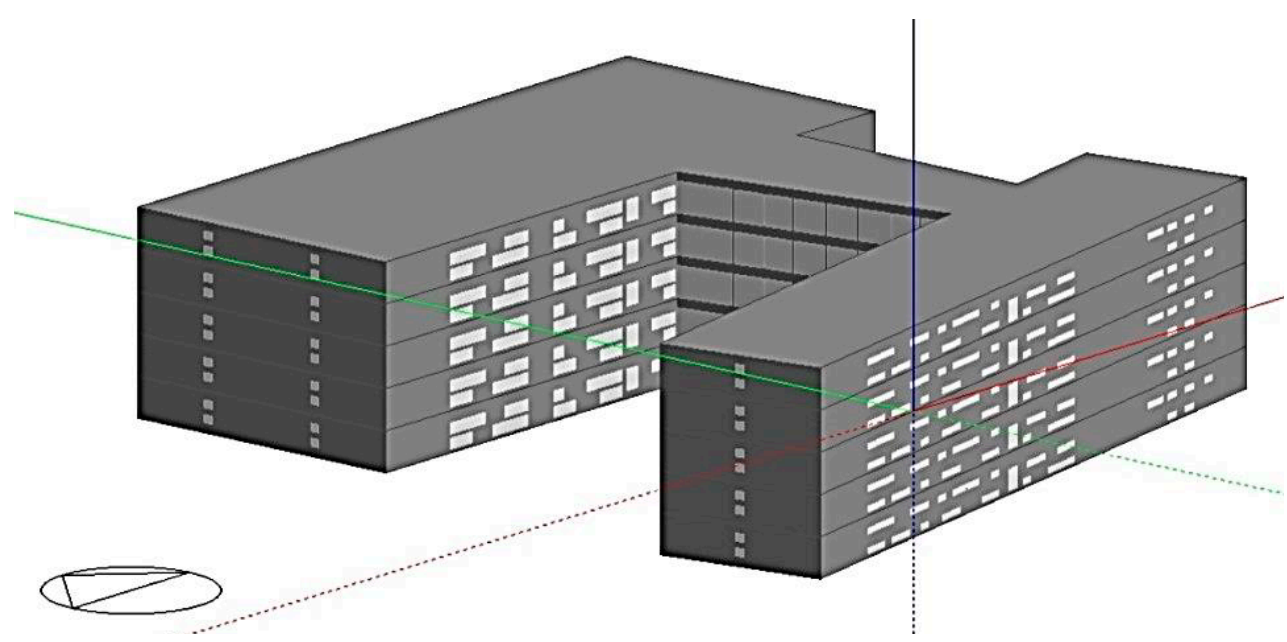

(a)

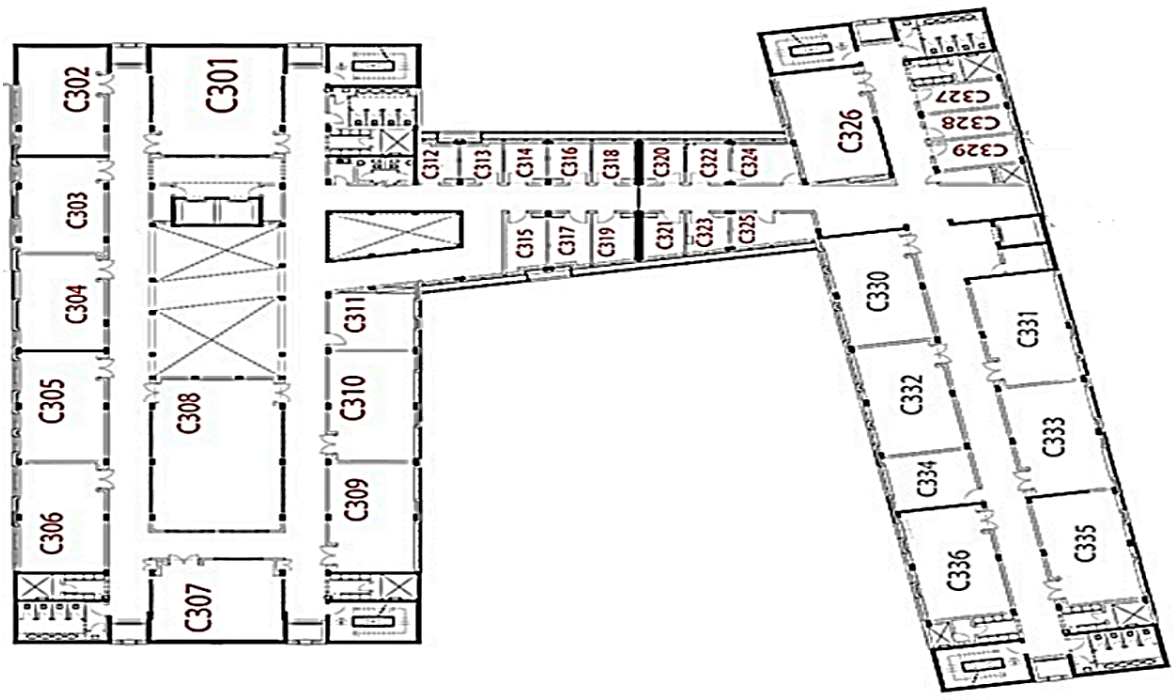

(b)

Figure 1. (a) Three-dimensional model of the studied building. (b) Floor plan of the studied building.

However, their corresponding thermal conductivity values were obtained from the literature/university laboratories and American Society of Heating, Refrigerating, and Air-Conditioning Engineers (ASHRAE) standard as follows [34]:

- The lighting in the building was designed as stated by ASHRAE 90.1 standard.

- The building can be divided into 4 thermal zones, which are classrooms, laboratories, offices, and corridors, since the aforesaid utilities are the only thermally conditioned areas of the building. Besides, they almost account for the heaviest energy consumption of the building by themselves.

- The building is supplied with 2 compression chillers with a cooling capacity of $710 \mathrm{~kW}$. One of the chillers also functions as a heat pump. This heat pump is aided by two 200 $\mathrm{kW}$ gas boilers that are installed for heating purposes. Moreover, the building is fitted with 3 air handling units to cover its ventilation load.

- The building ventilation load was calculated according to ASHRAE 62.1 standard.

The readings were obtained for monthly energy consumption from the Building Management System (BMS) for each month of 2019. Moreover, those readings were recorded by the BMS on an hourly basis per day. The data shown in Figure 2 resulted from the summation of the energy consumption of each day of the month. 
Table 2. Building materials and their corresponding thicknesses, thermal conductivity, and the overall heat transfer coefficient.

\begin{tabular}{|c|c|c|c|}
\hline & Layer Name & $\begin{array}{l}\text { Thermal Conductivity } \\
\text { (W/m K) }\end{array}$ & Thickness (mm) \\
\hline \multirow{5}{*}{ External Walls } & Stone & 2.2 & 50 \\
\hline & Concrete & 1.75 & 200 \\
\hline & Extruded polystyrene & 0.03 & 50 \\
\hline & Concrete Block & 1 & 13 \\
\hline & Cement Plaster & 1.2 & 20 \\
\hline & \multicolumn{3}{|c|}{ Overall heat transfer coefficient $=0.469 \mathrm{~W} / \mathrm{m}^{2} \mathrm{~K}$} \\
\hline \multirow{4}{*}{ Internal Walls } & Cement Plaster & 1.2 & 30 \\
\hline & Concrete & 1.75 & 200 \\
\hline & Cement Plaster & 1.2 & 30 \\
\hline & \multicolumn{3}{|c|}{ Overall Heat Transfer Coefficient $=1.61 \mathrm{~W} / \mathrm{m}^{2} \mathrm{~K}$} \\
\hline \multirow{4}{*}{ Roof Materials } & Asphalt & 0.7 & 20 \\
\hline & Extruded polystyrene & 0.03 & 59 \\
\hline & Concrete & 1.75 & 75 \\
\hline & Cement Plaster & 1.2 & 20 \\
\hline \multirow[b]{3}{*}{$\begin{array}{l}\text { External Windows } \\
\text { Frame Materials }\end{array}$} & \multicolumn{3}{|c|}{ Overall Heat Transfer Coefficient $=0.37 \mathrm{~W} / \mathrm{m}^{2} \mathrm{~K}$} \\
\hline & \multirow{2}{*}{$\begin{array}{l}\text { Aluminum } \\
\text { polyvinyl chloride } \\
\quad(\mathrm{pvc})\end{array}$} & 160 & 2 \\
\hline & & 0.17 & 5 \\
\hline Glazing & \multicolumn{3}{|c|}{$\begin{array}{c}\text { Overall Heat Transfer Coefficient }=5.01 \mathrm{~W} / \mathrm{m}^{2} \mathrm{~K} . \\
\text { Glazing Overall Heat Transfer Coefficient }=2.4 \mathrm{~W} / \mathrm{m}^{2} \mathrm{~K} \\
\text { Solar Factor }=24 \%\end{array}$} \\
\hline
\end{tabular}

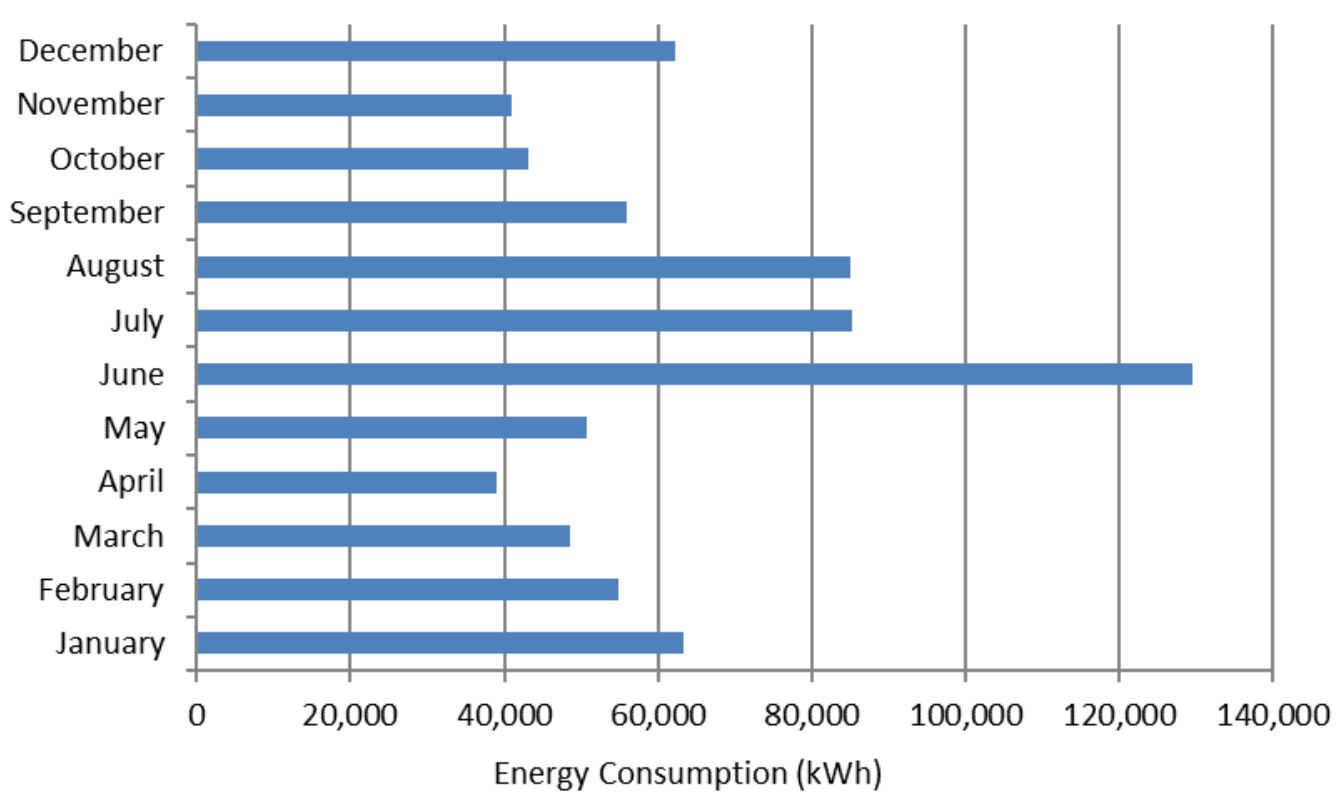

Figure 2. Actual (recorded from the site) energy consumption for each month.

\subsection{DesignBuilder Base Building Energy Model (BBEM) Interface}

The DesignBuilder software can be defined as a state-of-the-art graphic interface developed to produce the input file needed for the BBEM calculation. It can be referred to as 'DesignBuilder BBEM.' It offers major benefits to energy assessors.

Site-level allows the user to choose the location from the BBEM weather location dropdown menu. Moreover, it enables users to set the orientation of the building in degrees. The building is turned in a clockwise direction concerning the north arrow (this is generally best carried out after the model has been made). The orientation should 
always be used rather than the manual rotation of the building since it preserves the proper alignment of the axes.

The location used in the computerized modeling is the Queen Alia Airport because the exact building location in Madaba is not available in the software's location library. Furthermore, the hourly weather data for Queen Alia Airport was utilized for carrying out the annual simulation.

Building creation can be done either with or without the help of a 2-D drawing file created by a CAD system or by having a scan of the building plan. In both cases, 1 or more blocks are entered to define the building geometry.

The extruded block form is possibly the most useful. To create an extrusion block, a perimeter must be drawn using several predefined shapes. After that, the perimeter must be extruded by the required distance. Extrusions can be made either in horizontal planes or vertical ones.

Zone height, which is automatically calculated as the average zone height based on the block geometry, is entered.

DesignBuilder BBEM enables the process of loading building geometry from 2-D drawing files as a DXF file created by a CAD system or scanned images from other sources of building plans. It supports the most common formats. A possible alternative would be to import 3-D "BIM" files as gbXML files.

Areas occupied by both the ground and first floors were considered the same in the geometric model based on the assumption that the added area of the ground floor compensated for the removed area from the first. This assumption is thought to be valid because the building has no below-grade walls.

Both the building outline and internal partitions are needed to draw a building. It is recommended, therefore, to turn off the unwanted layers so that DXF files can be simplified in the CAD environment before exporting the DXF file. Block heights are also of great importance to energy assessors, so they may find it helpful to mark these on the CAD drawing. Furthermore, they could refer to a print of the 2-D drawing file when making a drawing of the building blocks.

The building is partitioned into zones following the BBEM zoning rules. Fewer blocks should be used to create the building, and then each block should be divided into zones by creating partitions between them as depicted by Figure 3. The building of interest mainly consists of offices, classrooms, and laboratories. Their numbers on each floor are shown in Table 1.

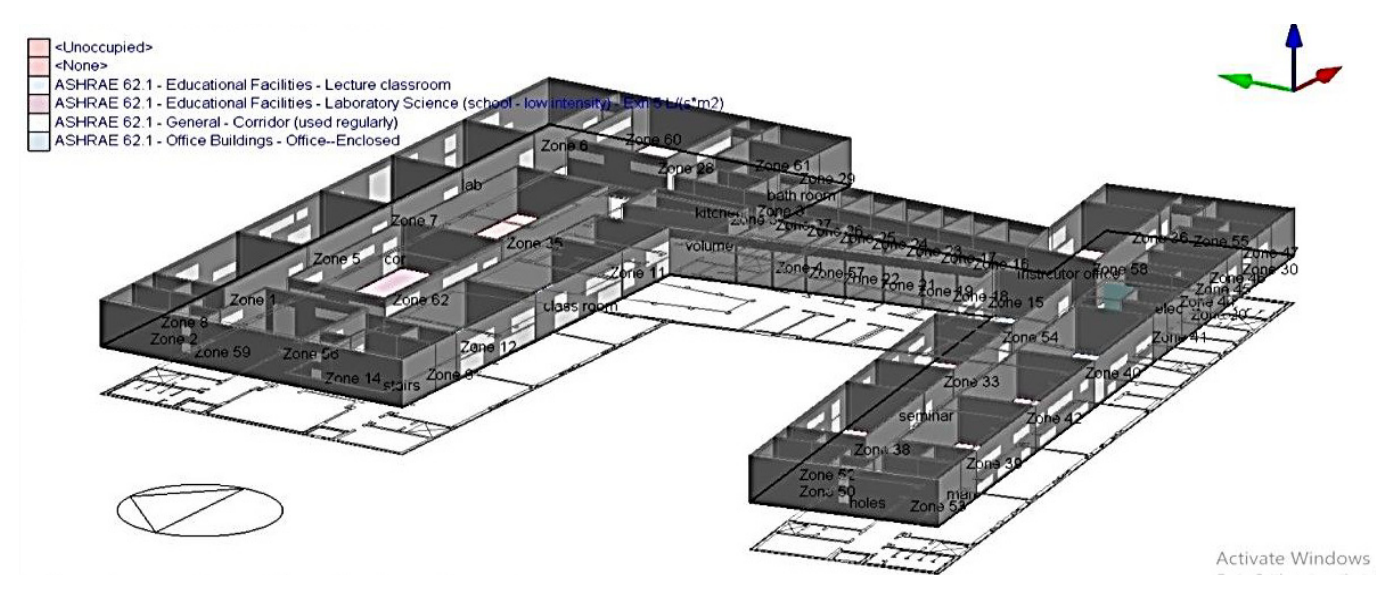

Figure 3. DesignBuilder visual interface.

Each envelope's zone is defined by the orientation, area, and properties of every physical boundary, including the floor, ceiling, wall, and roof, to calculate the BBEM. 
Constructions are treated simply in the BBEM calculation. The U-value, as well as the thermal mass, $\mathrm{Km}$, are needed to complete to the calculation. There are 3 techniques for entry:

- Introduction of own values: These values could come from either an independent source or automatic calculations done by DesignBuilder.

- Importing a construction from the library: This requires choosing from the lists, including solid (masonry) walls, cavity wall, pitched roof, flat roof, etc. After that, the building regulations which were in effect when the building was constructed, as well as the age bracket into which the building falls, can be selected.

- Inference procedures: These call for the selection of the sector, the building regulations which were in use at the time of construction, and a general description offered by the menus.

The lighting in the building was designed according to ASHRAE 90.1 standard and the building ventilation load was calculated according to ASHRAE 62.1 as shown in Table 3.

Table 3. Type of room and its lighting power density and ventilation rate.

\begin{tabular}{ccc}
\hline Room Type & $\begin{array}{c}\text { Lighting Power Density } \\
\text { (Lux) }\end{array}$ & $\begin{array}{c}\text { Ventilation Rate } \\
\text { (Liter/Second) Per Person }\end{array}$ \\
\hline Class Room & 467 & 3.8 \\
\hline Laboratory & 467 & 5 \\
\hline Office & 400 & 2.5 \\
\hline Corridor & 167 & 0.3 \\
\hline
\end{tabular}

The number of occupants was estimated according to survey of building occupants. The occupancy density and operating hours are shown in Table 4.

Table 4. Type of room and its occupancy density.

\begin{tabular}{ccc}
\hline Room Type & $\begin{array}{c}\text { Occupancy Density } \\
\text { (Person/Room) }\end{array}$ & Operating Days and Hours \\
\hline Class room & 65 & Sunday-Thursday 7:00 a.m.-5:00 p.m. \\
Laboratory & 25 & Sunday-Thursday 10:00 a.m.-5:00 p.m. \\
Office & 5 & Sunday-Thursday 7:00 a.m.-5:00 p.m. \\
Corridor & - & Sunday-Thursday 7:00 a.m.-5:00 p.m. \\
\hline
\end{tabular}

A survey was carried out for all the building running-electric equipment as shown in Table 5.

Table 5. Type of room and its plug load.

\begin{tabular}{cc}
\hline Room Type & Plug Load $\left(\mathbf{W} / \mathbf{m}^{2}\right)$ \\
\hline Class Room & 5 \\
Laboratory & 50 \\
Instructor office & 5 \\
Corridor & 3 \\
\hline
\end{tabular}

The building can be divided into 4 thermal zones-classrooms, laboratories, offices, and corridors-in view of the fact that the aforesaid utilities are the only thermally conditioned areas of the building. In addition, they almost account for the heaviest energy consumption of the building by themselves.

The building is supplied with 2 compression chillers with a cooling capacity of 202 tones. One of the chillers also functions as a heat pump. This heat pump is aided by two $200 \mathrm{~kW}$ gas boilers that are installed for heating purposes. Moreover, the building is 
fitted with 3 air handling units to cover its ventilation load. The building ventilation load was calculated according to ASHRAE 62.1 standard.

\subsection{Building Management System (BMS)}

Our main approach in achieving a thermally adaptive environment is to monitor and control the condition for each room. A building management system was used to help with this task. The actual building contains a building management system (BMS). Data from the BMS were used to calibrate the accuracy of the simulated model.

The BMS is a microprocessor with a controller network installed to monitor and control building services and technical systems such as individual energy consumptions, access control, security, lifts, air-conditioning, lighting, operative temperature, and ventilation. The BMS controls and monitors mechanical and electrical components that control those technical services. Those main components have a primary connection and roots into branches for the building, which also roots to tertiary branches (Supply and return) to every room. Hence, readings at those points could be measured and saved for every room.

The BMS uses real-time monitoring for measuring the temperature of each branch of those components and records them every hour. Graphical trending is also available in the system, which is useful for determining the stability control algorithms and tuning the system, as well as time scheduling of the BMS (i.e., it tells the components when to start and stop). Real lifetime monitoring could also help us inspect if the components are not working on their optimal efficiency, whether the reduced efficiency is caused by a leakage of some type, the component is up for maintenance, or the component needs to be renewed.

The BMS monthly energy consumption is shown in the Table 6 . The readings were obtained from the BMS for each month of 2019. Moreover, those readings were recorded by the BMS on an hourly basis per day, documented the energy consumption of each day of the month.

Table 6. Monthly energy consumption.

\begin{tabular}{cc}
\hline Month & Energy Consumption (MWh) \\
\hline January & 63.4 \\
February & 54.9 \\
March & 48.6 \\
April & 39 \\
May & 50.7 \\
June & 130 \\
July & 85.1 \\
August & 84.9 \\
September & 55.9 \\
October & 43.1 \\
November & 41 \\
December & 62.3 \\
\hline
\end{tabular}

\subsection{Thermal Comfort}

The American Society of Heating, Refrigerating, and Air-Conditioning Engineers (ASHRAE) Standard 55:2004 defines human thermal comfort as a "condition of mind which expresses satisfaction with the thermal environment." The thermal sensation of warmth or coldness is highly subjective and is different for every individual. It depends on 4 environmental factors (air temperature, mean radiant temperature, humidity, and air movement), 2 personal factors (metabolic rate and clothing insulation), and 1 psychological factor (expectation) [35].

Deep normal body temperature in humans is close to $37.2{ }^{\circ} \mathrm{C}$, independent of environmental temperature and higher than the global ambient temperature. Therefore, heat is constantly evacuated through our skin to the surrounding air to compensate for our metabolic dissipation at a rate that maintains thermal equilibrium in the body, i.e., the body's thermal equilibrium is when the heat generated within the body equals heat loss by 
the body. Metabolism is the biological chemical transformation within body cells to convert consumed food into energy to run cellular processes with an efficiency of approximately $20 \%$. The generated amount of heat by a human body depends on the number of body cells. Thus, body response is shown in many ways, such as sweating or shivering to maintain the thermal equilibrium in the body. Commonly, 4 different cooling mechanisms occur within the human body through evaporation, radiation, convection, and conduction [36].

As mentioned before, human comfort is influenced by various factors such as activity, clothing, age, gender, etc. As a result, there is no strict standard that can outline the ultimate atmospheric conditions for comfort for all individuals in the same surroundings. Consequently, ASHRAE (Standard 55) conducted different studies to determine the range of commonly acceptable combinations of temperature and relative humidity in a controlled indoor environment. The results showed that the acceptable range of operative temperature in typical winter office varies from $20-24.5^{\circ} \mathrm{C}$, and the maximum acceptable range of operative temperature in typical summer office varies from $25.5^{\circ} \mathrm{C}$ at $60 \%$ relative humidity to $26.5^{\circ} \mathrm{C}$ at $30 \%$ relative humidity. However, the minimum acceptable range of operative temperature is around $23^{\circ} \mathrm{C}$ [35].

Practically, $98 \%$ of occupants are thermally satisfied when the temperature and relative humidity integration take place in the comfort zone suggested by ASHRAE, as shown in Figure 4. Consequently, a person will feel almost exactly as cool at $24{ }^{\circ} \mathrm{C}$ and $60 \%$ relative humidity as at $26^{\circ} \mathrm{C}$ and $30 \%$ relative humidity [36].

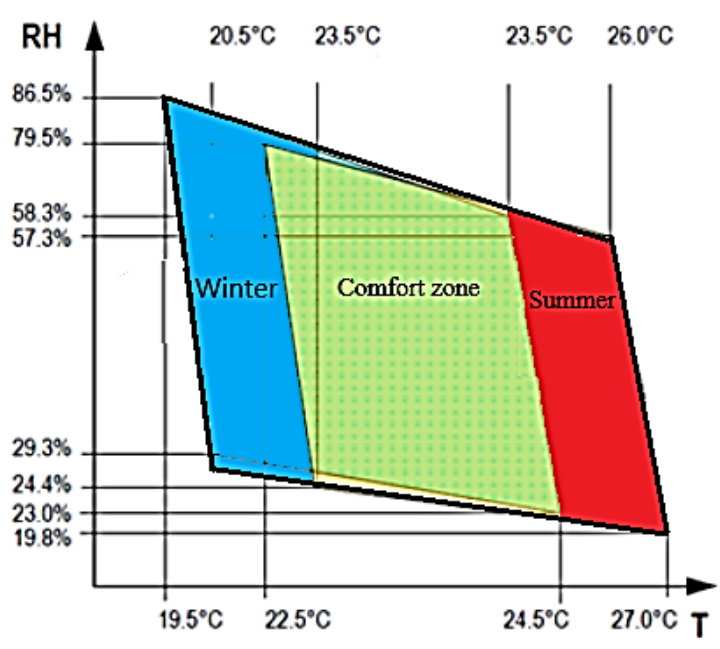

Figure 4. ASHRAE comfort zones for winter and summer air-conditioning.

Regardless of the location of the building in the world, ASHRAE standards for natural ventilation prove that there is no distinction in the mean preferred temperature for individuals referring to the same outdoor temperature, whereby the domain of acceptable temperature inside any building relies on the outside temperature. The specified temperature range complies with $90 \%$ and $80 \%$ of the acceptance limits and can reach approximately $30{ }^{\circ} \mathrm{C}$ according to ASHRAE 55-2017 standard [35], as shown in Figure 5 . 


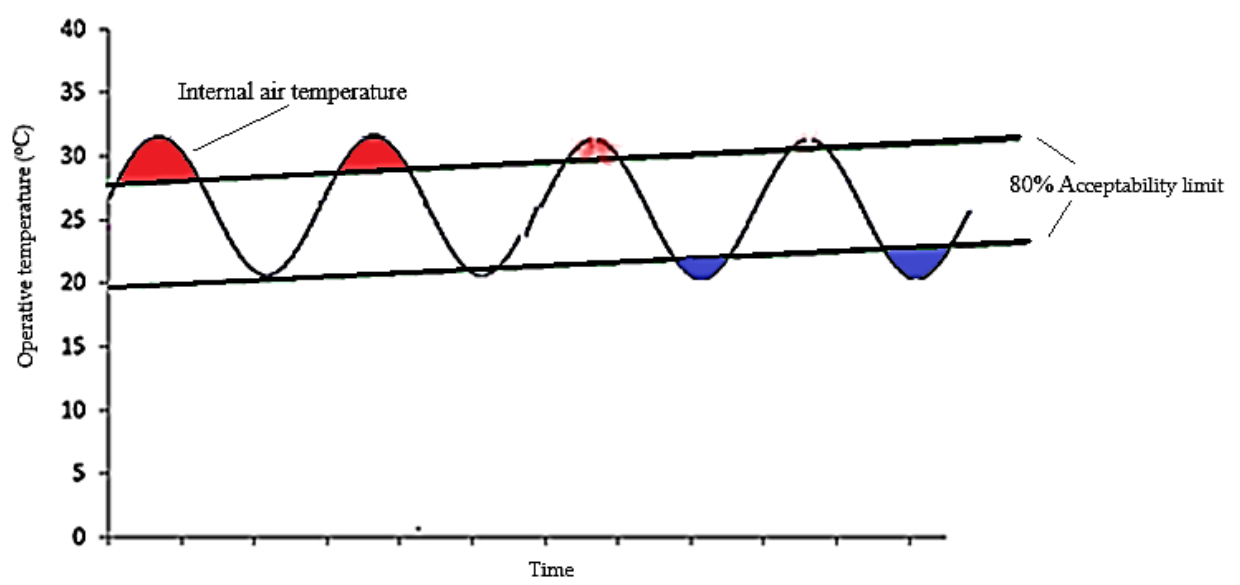

Figure 5. The $80 \%$ acceptability limits for indoor temperature are based on the mean outdoor temperature.

The European thermal adaptive comfort standard BS EN 16798-1 is based on ASHRAE 55 , and the comfort temperature is calculated in the same way (similar equations but with different coefficients). As there is currently no Australian standard, ASHRAE 55 has been adopted. The adaptive thermal comfort temperature for free-running buildings (the comfort temperature $\mathrm{T}_{\mathrm{c}}$ ) can be calculated through this equation [36]:

$$
\mathrm{T}_{\mathrm{C}}=17.8+0.31 \times \mathrm{T}_{\mathrm{o}}
$$

where $T_{o}$ is the mean of the outdoor air temperature for the past 30 days $\left({ }^{\circ} \mathrm{C}\right), \mathrm{T}_{\mathrm{C}}$ is the thermal neutrality $\left({ }^{\circ} \mathrm{C}\right)$, and $\mathrm{T}_{\mathrm{o}}$ is used to find the adaptive thermal comfort $80 \%$ acceptability limits inside the building, where at least $80 \%$ of the occupants are satisfied with these temperature ranges $\left(80 \%\right.$ acceptability limits $\left.=\mathrm{Tc} \pm 3.5^{\circ} \mathrm{C}\right)[36]$.

In Madaba, Jordan, applying the adaptive thermal comfort model will result in a wider range of temperatures. The thermal comfort temperature zones were expanded to $24^{\circ} \mathrm{C}$ and $29^{\circ} \mathrm{C}$ in the summer and $19^{\circ} \mathrm{C}$ to $25^{\circ} \mathrm{C}$ in the winter. These wider ranges would save massive amounts of operational energy if adopted.

Human beings feel comfortable within a range of temperature conditions. Humans have a body temperature of about $37^{\circ} \mathrm{C}$. Even though the human body builds up the heat when it is not moving, which also acts as a parameter in the HVAC load, heat loss must be identical to the rate at which heat is produced. Furthermore, heat gain must be the same as the rate at which heat is lost.

The C-building is a new building built in 2011 with high-technology monitoring and operating systems such as the BMS, which records the temperature inside each room in the building. The temperature is set and maintained between $22-24^{\circ} \mathrm{C}$ throughout the year. In theory and in reality, the temperature of $22{ }^{\circ} \mathrm{C}$ for heating and $24^{\circ} \mathrm{C}$ for cooling varies in some rooms due to the occupant's behavior in those rooms.

In the simulation, we examined the building's energy consumption when operated at three different scenarios. The first scenario $\left(1^{\circ} \mathrm{C}\right)$ was the baseline, which was operated at an HVAC temperature of $21^{\circ} \mathrm{C}$ for heating and $25^{\circ} \mathrm{C}$ for cooling. The second scenario $\left(2{ }^{\circ} \mathrm{C}\right)$ was operated at 2 degrees below the baseline heating temperature and 2 degrees higher the baseline cooling temperature, or $20^{\circ} \mathrm{C}$ for heating and $26^{\circ} \mathrm{C}$ for cooling. The final scenario $\left(3^{\circ} \mathrm{C}\right)$ awas 3 degrees higher for cooling and 3 degrees lower for heating compared with the base design $\left(19^{\circ} \mathrm{C}\right.$ for heating and $27^{\circ} \mathrm{C}$ for cooling, which is still within the $80 \%$ adaptive acceptability limits).

\subsection{Research Methodology (Workflow)}

An energy model of an educational building located at the German Jordanian University in Jordan was constructed utilizing DesignBuilder computer software using real data 
recorded on the site. Then, a comparison between the real building and the simulation in terms of real energy consumption data for a 12-month simulation of energy performance was performed. The comparison was followed by a computerized evaluation of the roles of building envelope retrofits. The adaptive thermal comfort limits in the reduction of the overall building energy consumption were also analyzed.

\section{Results and Discussion}

\subsection{Baseline Case}

Figure 6 illustrates the percentages of electrical energy consumption of the building by four main types of loads. Overall, the building's heaviest energy consumer was the plug load (machines in the laboratories and the workshops). This was followed by cooling and lighting, respectively. However, the building's lightest energy consumer was heating.

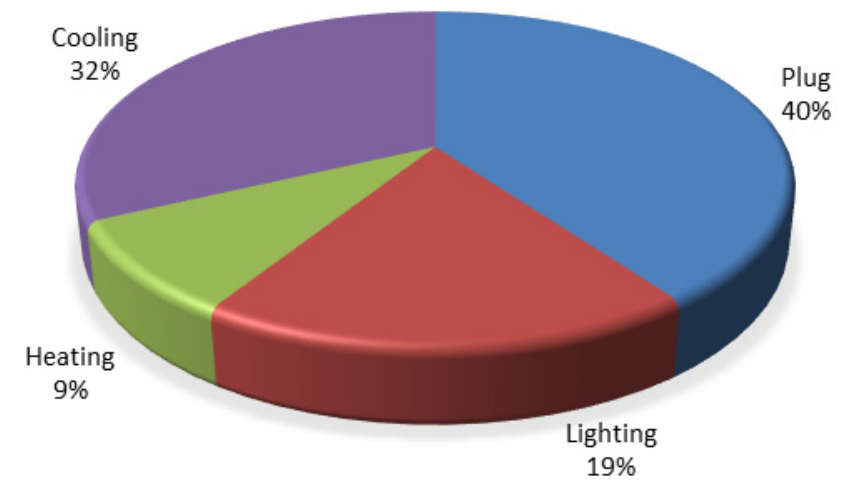

Figure 6. Types of the building's loads.

From the data in Figure 6, the plug load constituted the highest energy consumption of the building at $40 \%$. This was closely followed by the cooling load, which accounted for $32 \%$ of the building's energy consumption. Other loads of the building included lighting, which accounted for $19 \%$ of the building's energy consumption, and heating, which comprised the lowest energy consumption of the building at $9 \%$. This was due to a high heat generation from internal loads, such as cooling, lighting, and occupants. On the other hand, this factor increased the cooling load significantly.

The building's northerly and southerly directions have the highest window-to-wall ratio, with $29 \%$ and $27 \%$ each. By contrast, the easterly and westerly directions have the lowest window-to-wall ratios, with $26 \%$ and $19 \%$ respectively.

Regarding the wall gross area, the largest areas are occupied by the east and the west walls, with $2.27 \mathrm{e}^{+3} \mathrm{~m}^{2}$ and $2.19 \mathrm{e}^{+3} \mathrm{~m}^{2}$, respectively. On the other hand, the smallest are the northerly and southerly direction walls, with $1.28 \mathrm{e}^{+3} \mathrm{~m}^{2}$ and $1.23 \mathrm{e}^{+3} \mathrm{~m}^{2}$ each. It is worth mentioning that the whole building has no floor below ground level.

Figure 7 provides a comparison between the real building and the simulation in terms of energy consumption during all months of the year. Overall, the main trend for the energy consumption of the real building and simulation was upward during the summer months. On the other hand, there was a downward trend for the energy consumption of the real building and simulation during the winter months. Besides, the energy consumption of the real building differed from that of the simulation during transition months. 


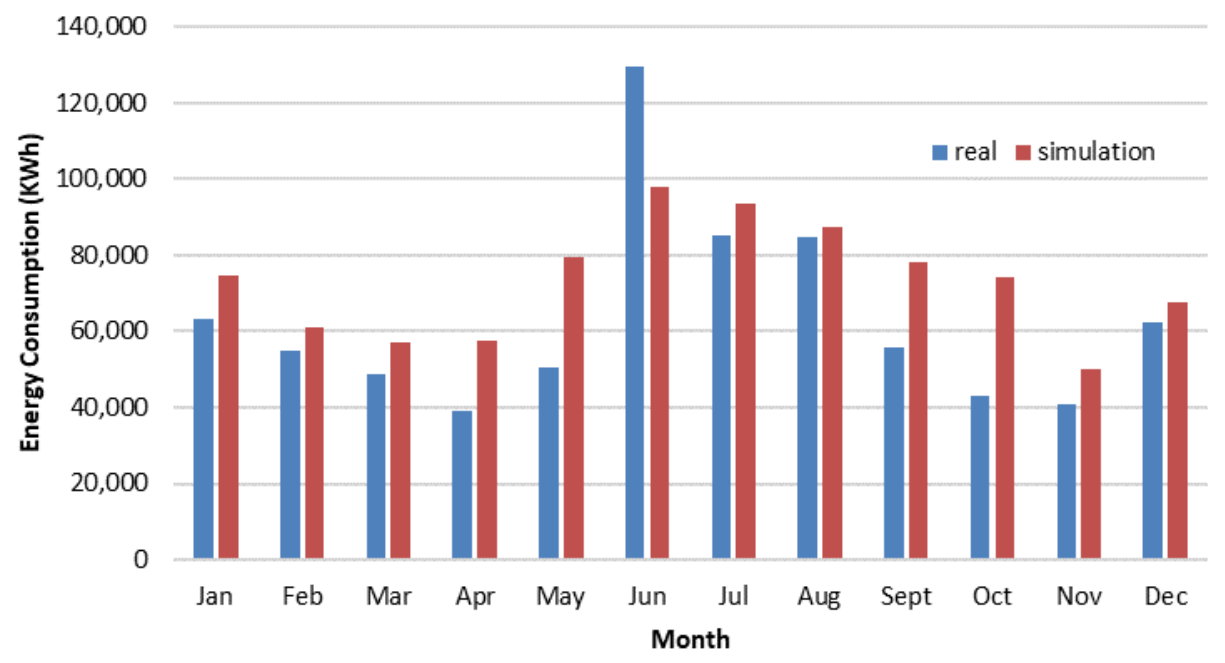

Figure 7. Comparison between the real building's energy consumption with the simulation results.

From the data in Figure 7, it is apparent that the energy consumption of both the real building and the simulation was higher in summer months, i.e., June, July, August, and September, than any time of the year, since the cooling load was dominant, accounting for almost twice the heating load even though the building's working hours during summer months were shorter. According to the results, the highest number for energy consumption of the real building was recorded in June at $130 \mathrm{MWh}$. Similarly, the energy consumption of the simulation was highest in June at $98 \mathrm{MWh}$. Also, in May, the energy consumption was significantly lower than in June due to the cooler temperature in May, as it is a transitional time between the winter and summer. Also, during May, Ramadan started, which resulted in shorter working hours for students and the academic staff. In June, the second semester final exams started and all the rooms and laboratories were occupied most of the time, resulting in higher energy consumption.

As can be seen from Figure 7, the main trend for energy consumption of the real building and the simulation was downward during winter months, namely December, January, February, and March. Moreover, the amount of energy consumed by the real building and the simulation during these months was almost the same. As far as energy consumption in winter is concerned, January saw the highest consumption of energy for the real building at $63 \mathrm{MWh}$. Similarly, the highest energy consumption for the simulation was logged in January at $75 \mathrm{MWh}$. The data in Figure 7 indicate that the energy consumption of the real building varied from that of the simulation during transition months, i.e., April and October. According to the figures, the energy consumption of the real building was $43 \mathrm{MWh}$, whereas that of the simulation was $74 \mathrm{MWh}$ in October. In April, energy consumption comprised $39 \mathrm{MWh}$ and $57 \mathrm{MWh}$ for the real building and simulation, respectively.

Figure 8 compares the cooling and heating loads of the real building with those of the baseline. Overall, the cooling loads of both the real building and the simulation model were much higher than their heating loads. Besides, there was a noticeable difference between the real building and the simulation model in terms of the cooling load. However, the heating load of the real building was almost the same as that of the baseline.

From the data in Figure 8, it is obvious that the cooling load of the building was higher than its heating load. In fact, the cooling load was 1.4 MW for the real building and 1.3 MW for the baseline, while the heating load was $0.64 \mathrm{MW}$ for the real building and 0.61 MW for the baseline. In Sections 3.2 and 3.3, a detailed analysis of utilizing LED and economizer is carried out. 


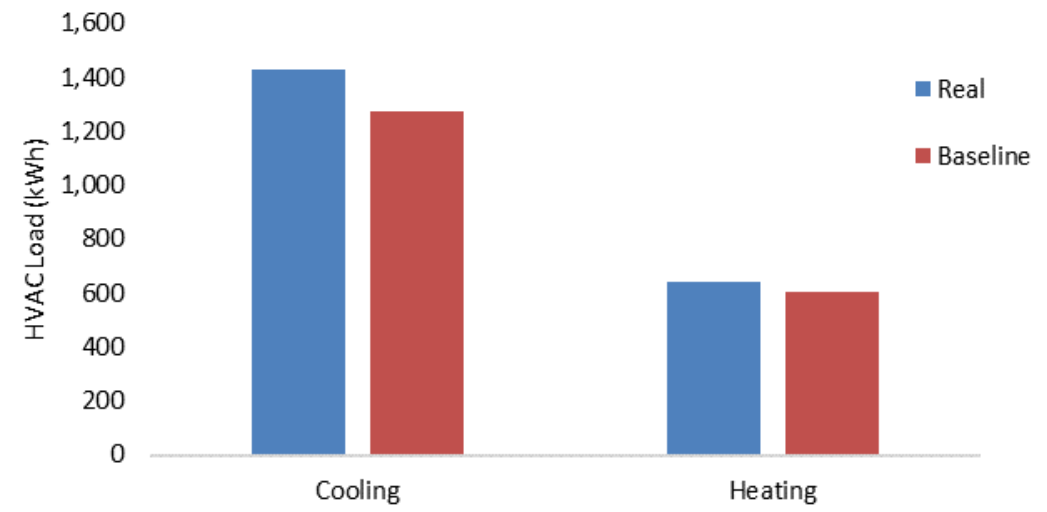

Figure 8. Cooling and heating HVAC loads of the real building and the baseline (simulated).

\subsection{Utilizing $L E D$}

A simulation using efficient LED (90 lumens/watt) was carried out to determine whether LED lighting saves more energy than conventional lighting. The simulation indicated that LED lighting achieved an annual energy savings of $38 \mathrm{MWh}$. The effect of using an LED lighting fixture on the building's energy indicates that cooling energy consumption significantly decreased in summer months, i.e., June, July, August, and September, because the LED lighting fixture generated less heat. In addition, it drew less electric energy in comparison to conventional lighting fixtures as shown in Figure 9.

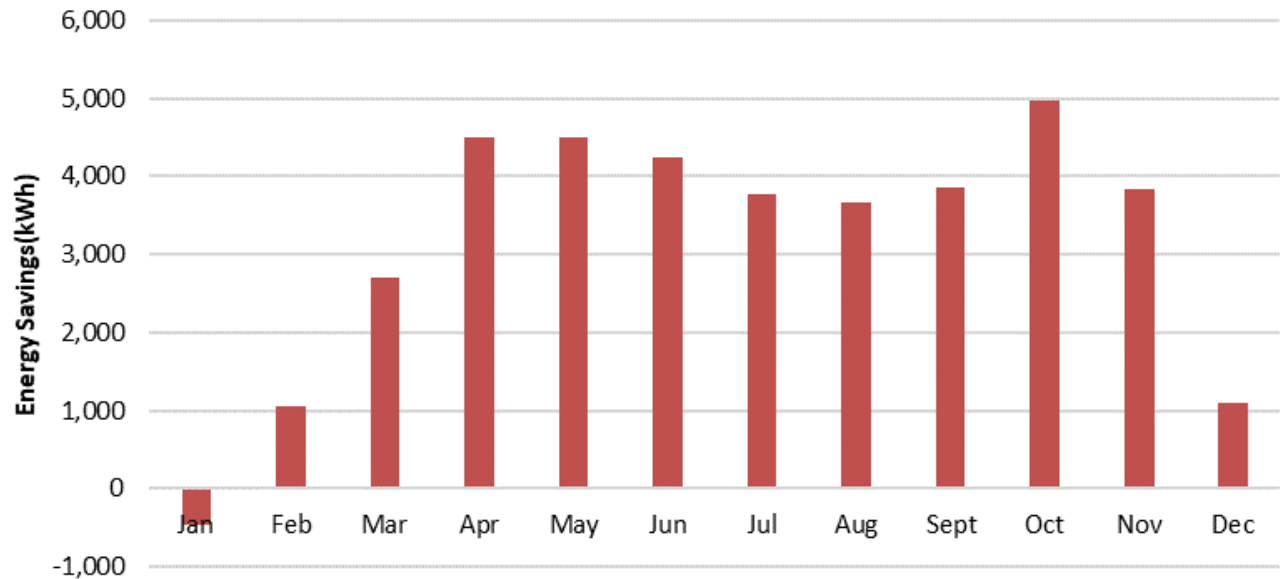

Figure 9. Energy savings achieved by utilization of the LED lighting fixture.

According to the results, the cooling load of the real building is higher than that of the baseline, with a difference of around $155 \mathrm{~kW}$. On the other hand, there is a slight difference of $35 \mathrm{~kW}$ between the heating load of the real building and that of the baseline.

\subsection{Utilizing Economizers and Heat Recovery}

When the BMS indicates the need for cooling, a signal will first move through the control board located at rooftop and over to the economizer control. Then, the economizer control unit will pick whether to continue with free cooling or mechanical cooling. If the outside air temperature is not suitable for free cooling, then the control will initiate mechanical cooling (compressor operation). If the outdoor air is suitable for free cooling, then the outdoor air dampers will modulate to maintain the mixed air or discharge air setpoint until the desired temperature is reached. Once the thermostat has been satisfied, the call for cooling will stop.

Economizers do not normally have heat recovery or energy recovery function, so ventilating with an economizer can have an energy drawback compared to a heat recovery 
ventilator. The effect of using an economizer and heat recovery unit on the building's energy consumption can be seen in Figure 10, which shows the energy savings made using economizer during 12 months of the year. Overall, there was hardly any energy savings using the economizer during winter months, whereas significant savings in energy were achieved during summer months.

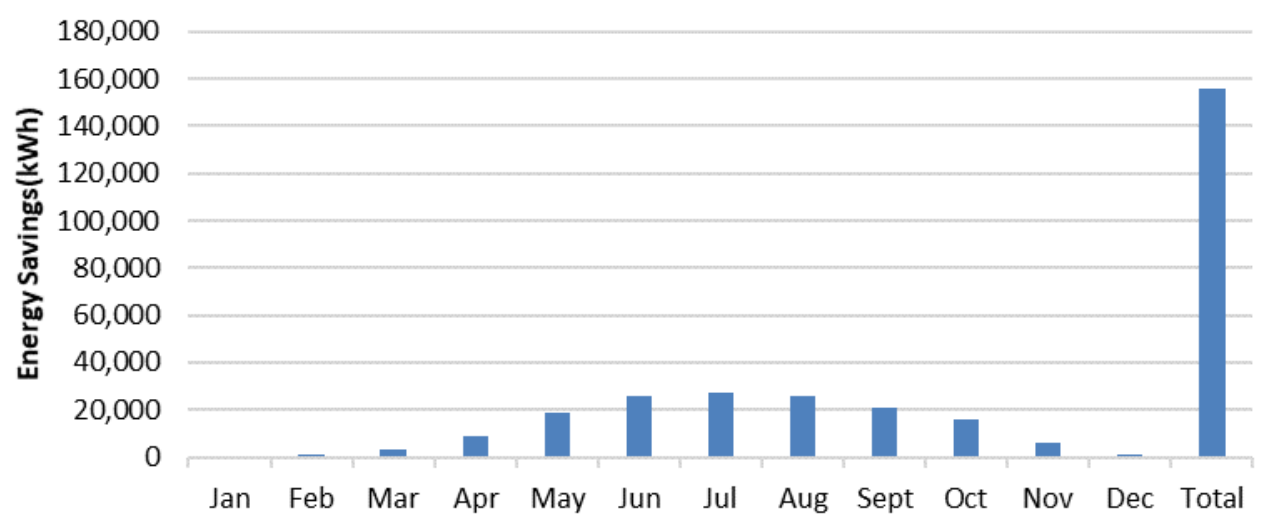

Figure 10. Energy savings achieved by utilization of the economizer.

The data in the Figure 10 indicate that significant energy savings came from using the economizer during summer months, i.e., June, July, August, and September compared with little energy savings made during winter months, namely January, February, and December. The annual energy savings achieved using the economizer amounted to $155 \mathrm{MWh}$.

Figure 11 illustrates the energy savings achieved throughout the year utilizing a heat recovery unit. Overall, the use of heat recovery resulted in energy savings in summer and winter months. However, the energy savings in summer months were higher than those in winter months.

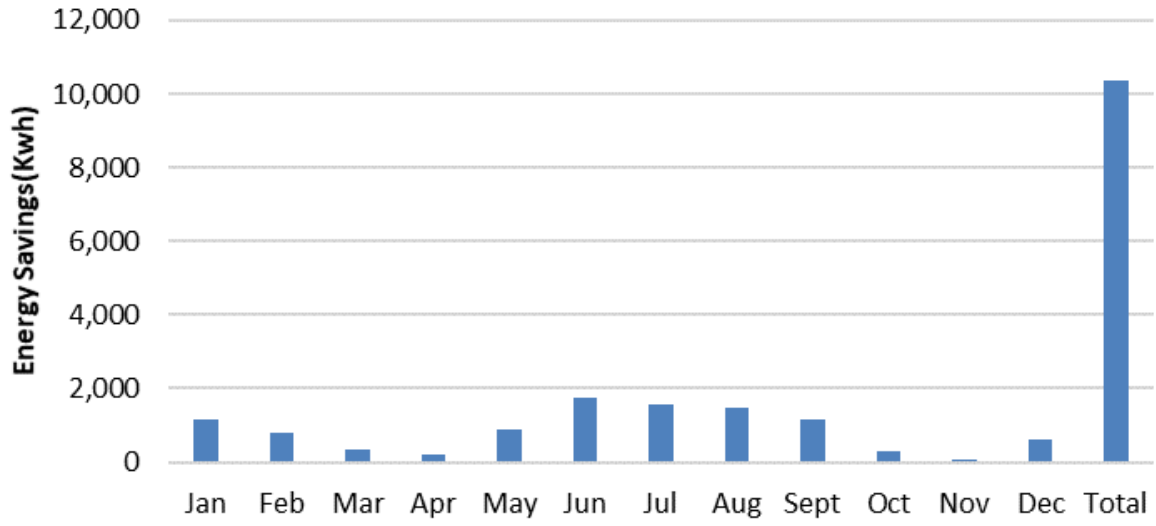

Figure 11. Energy savings achieved by utilization of the heat recovery unit.

Figure 11 shows that, as far as energy savings from the use of heat recovery are concerned, summer months saw more savings in energy than winter months.

To sum up, the economizer achieved more savings in energy than heat recovery. In fact, energy savings made using the economizer were 15 -fold greater than those made using the heat recovery unit.

Table 7 shows the initial costs, annual savings, Net Present Value (NPV), Internal Rate of Return (IRR), and Pay Back Period (PBP) of the heat recovery unit and economizer. The annual energy savings made by the economizer were higher than those made by the heat unit recovery. Whereas the latter made USD 1.04K annual savings, the former achieved USD 15K annual savings. However, the initial costs associated with using the economizer were higher than those associated with using the heat recovery unit, with USD 50K and 
USD 15K apiece assuming that the electricity tariff for educational buildings in Jordan USD $0.10 / \mathrm{kWh}$, the study period is 10 years, and the interest rate is $5 \%$.

Table 7. The initial costs, annual savings, NPVs, IRRs, and PBPs of the heat recovery unit and economizer.

\begin{tabular}{ccc}
\hline Component & Heat Recovery & Economizer \\
\hline Cost $($ \$USD) & $15 \mathrm{~K}$ & $50 \mathrm{~K}$ \\
\hline Annual savings (\$USD) & $1.03 \mathrm{~K}$ & $15.5 \mathrm{~K}$ \\
\hline NPV $($ \$USD) & $-6.6 \mathrm{~K}$ & $66.7 \mathrm{~K}$ \\
\hline IRR $(\%)$ & $-6 \%$ & $29 \%$ \\
\hline PBP $(\mathrm{yr})$ & 27 & 4 \\
\hline
\end{tabular}

A loss accrued from utilizing the heat recovery unit, with a NPV of USD $-6.7 \mathrm{~K}$, whereas a huge profit arose from using the economizer, with a NPV of USD 66.7K over the studied period. The IRR for using the economizer was higher $(29 \%)$, while using the heat recovery unit resulted in losses. Nevertheless, the PBP for using the heat recovery unit was infeasible compared with using the economizer.

\subsection{The Effect of HVAC Set Temperature Points on the Building's Energy Consumption (Adaptive Limits)}

In Madaba, Jordan, applying the adaptive thermal comfort model will result in a wider range of temperatures. The thermal comfort temperature zones could be expanded from $24^{\circ} \mathrm{C}$ to $27^{\circ} \mathrm{C}$ in hot summer months and from $22^{\circ} \mathrm{C}$ to $19{ }^{\circ} \mathrm{C}$ in cold winter months. These wider ranges would save massive amounts of operational energy if adopted.

The baseline (business as usual) is operated at the HVAC design temperature of $22{ }^{\circ} \mathrm{C}$ for heating and $24^{\circ} \mathrm{C}$ for cooling. Figure 12 shows the building's energy consumption when operated at three different scenarios. The first scenario $\left(1^{\circ} \mathrm{C}\right)$ was the baseline, which was operated at an HVAC temperature of $21^{\circ} \mathrm{C}$ for heating and $25^{\circ} \mathrm{C}$ for cooling. The second scenario $\left(2^{\circ} \mathrm{C}\right)$ was operated at two degrees below the baseline heating temperature and two degrees higher the baseline cooling temperature, or rather $20^{\circ} \mathrm{C}$ for heating and $26^{\circ} \mathrm{C}$ for cooling. The final scenario $\left(3^{\circ} \mathrm{C}\right)$ was three degrees higher for cooling and three degrees lower for heating compared with the base design $\left(19^{\circ} \mathrm{C}\right.$ for heating and $27^{\circ} \mathrm{C}$ for cooling, which is still within the $80 \%$ adaptive acceptability limits).

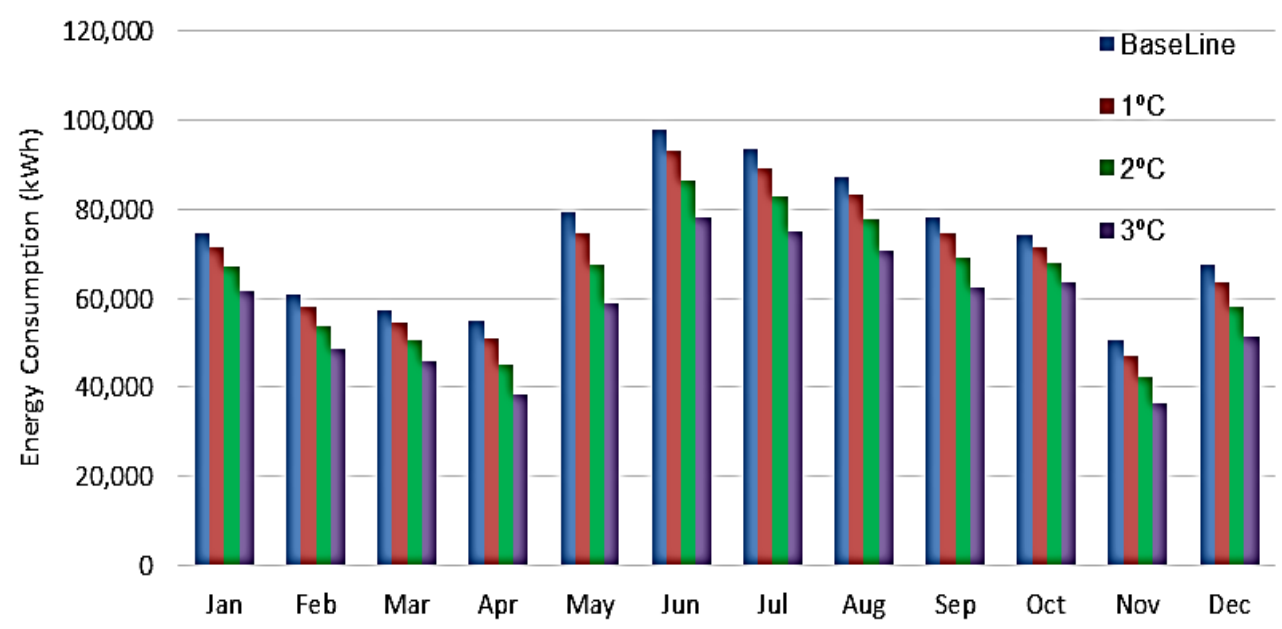

Figure 12. The effect of HVAC temperature setpoints on the building's energy consumption.

The building's additional energy savings was determined for the different three scenarios. For the first scenario $\left({ }^{\circ} \mathrm{C}\right)$, the energy savings were $43.8 \mathrm{MWh} /$ year, which 
was around 5\% lower than the baseline. The total energy savings of $108 \mathrm{MWh} / \mathrm{year}$ and $185 \mathrm{MWh}$ /year for the second and the third scenarios was around 12\% and 21\% lower than baseline, respectively. Overall, the building's additional energy savings significantly increased when the cooling temperatures were increased and when the heating temperatures were decreased.

\subsection{Summary of the Studied Retrofit Cases}

Simulations were performed to examine the effect of each retrofit on the final energy consumption. The results were as follows:

- Wall insulation thickness was increased by $5 \mathrm{~cm}, 10 \mathrm{~cm}, 15 \mathrm{~cm}$, and $20 \mathrm{~cm}$ to achieve more energy savings. However, the biggest annual energy savings, amounting to $18 \mathrm{MWh}$ /year, were achieved by adding $20 \mathrm{~cm}$ walls. However, adding $20 \mathrm{~cm}$ walls was too costly, and just increasing the insulation thickness by $5 \mathrm{~cm}$ saved around $12.5 \mathrm{MWh} /$ year.

- Roof insulation thickness was increased by $5 \mathrm{~cm}, 10 \mathrm{~cm}$, and $15 \mathrm{~cm}$ to achieve more energy savings. The results show that adding $15 \mathrm{~cm}$ insulation roofs led to the biggest annual energy savings, which amounted to 27.9 MWh. In addition, the U-value changed as the roof insulation thickness increased. For practical purposes, $5 \mathrm{~cm}$ will be used for this comparison.

- Four different types of glazing were utilized to achieve energy savings. The replacement of the existing glazing by the glaze with a U-value of $1.1 \mathrm{~W} / \mathrm{m} 2$ and solar constant of 0.17 attained 43.2 MWh annual energy savings with a 6-year payback period. Based on this study, it can be concluded that the utilization of triple glazing with higher reflectivity led to the biggest annual energy savings.

- Three kinds of overhangs with varying projection lengths $(0.5 \mathrm{~cm}, 1.0 \mathrm{~cm}$, and $1.5 \mathrm{~cm})$ were employed to achieve energy savings. In conclusion, the employment of $0.5 \mathrm{~cm}$ created the greatest annual energy savings, which amounted to 13.3 MWh.

- $\quad$ Three different types of louvers with varying projection lengths $(0.5 \mathrm{~m}, 1 \mathrm{~m}$, and $1.5 \mathrm{~m})$ were used to achieve energy savings. In summary, the use of $1.5 \mathrm{~m}$ louvers resulted in the biggest annual energy savings of $16 \mathrm{MWh}$.

- A simulation of seven different orientations of the building was carried out to conclude the most energy-efficient orientation. The rotation of the building was a hypothetical situation to cover a wide range of scenarios. This simulation shows that the baseline, i.e., the original building's orientation, was the most energy-efficient, with the least annual energy consumption.

- The economizer and heat recovery unit was utilized to achieve more energy savings. To sum up, energy savings achieved by the economizer were 15-times higher than those made by the heat recovery unit. Whereas the latter achieved 10.4 MWh, the former achieved $156 \mathrm{MWh}$ annual energy savings.

- A simulation in which the building was lit through LED was carried out to determine whether LED lighting saves more energy than conventional lighting. The simulation indicated that LED lighting achieved an annual energy savings of 37.7 MWh.

Table 8 summarizes the simulation results obtained from each retrofit case and the adaptive scenarios, which show the advantage of applying the heating and cooling adaptive scenarios compared to all retrofits with the least cost. The costs depend on the country, materials, and level of finish, so we generalize the cost by 'high cost,' which is more than USD 200k; 'medium cost,' which is less than USD 200k but higher than USD 50k; 'low cost,' which is less than USD 50k; and 'null,' which does not cost anything to apply. 
Table 8. Summary of the simulation results obtained from each retrofit case and the adaptive scenarios.

\begin{tabular}{ccc}
\hline Case & $\begin{array}{c}\text { Annual Energy } \\
\text { Savings (MWh) }\end{array}$ & Cost \\
\hline Increase of wall insulation thickness by $5 \mathrm{~cm}$ & 12.5 & High \\
Add 0.5 m projection lengths to the windows & 13.3 & High \\
Add louvers with projection lengths $1.5 \mathrm{~m}$ & 16 & High \\
Increasing roof insulation thickness by $5 \mathrm{~cm}$ & 22.2 & High \\
Utilization of LED lighting & 37.8 & Low \\
Replacement of glazing by triple glazing & 43.2 & Medium \\
First heating and cooling adaptive scenario $\left(1^{\circ} \mathrm{C}\right)$ & 43.8 & Almost Null \\
Second heating and cooling adaptive scenario $\left(2^{\circ} \mathrm{C}\right)$ & 7.8 & Almost Null \\
Installation of ventilation air economizer & 155 & Medium \\
Third heating and cooling adaptive scenario $\left(3^{\circ} \mathrm{C}\right)$ & 185 & Almost Null \\
\hline
\end{tabular}

\section{Conclusions}

Overall, this study compared the energy consumption of various types of buildings' envelope retrofits such as increasing the insulation layer of external walls and roof, replacing windows' glazing, and adding shading devices to wider ranges of adaptive thermal comfort limits. Moreover, it also assessed the potential of installing a ventilation air economizer in attaining both energy and financial savings.

The real building and simulation model were compared in terms of their heating and cooling loads. This comparison showed that the real building's and the simulation model's cooling loads were higher than their heating loads. In addition, the real building's cooling load was greater than that of the simulation. In contrast, the real building's heating loads differed slightly from those of the simulation (less than $10 \%$ in most cases).

Different retrofit options were considered to achieve indoor thermal comfort (summarized in Table 8), and the annual energy saved was compared with different scenarios for the heating and cooling loads based on the adaptive model. Overall, the building's additional energy-saving significantly increased when the cooling temperatures were increased and when the heating temperatures were decreased. Using different adaptive thermal comfort scenarios $\left(1{ }^{\circ} \mathrm{C}, 2{ }^{\circ} \mathrm{C}\right.$, and $\left.3{ }^{\circ} \mathrm{C}\right)$ led to significant savings of around $5 \%, 12 \%$, and $21 \%$, respectively. However, using different retrofit techniques proved to be costly, with minimum energy savings compared to the adaptive approach.

The results were completely in favor of adopting the adaptive limits as a way of saving energy with almost no cost. These adaptive limits promote sustainability over any kind of retrofit made to the existing building.

Author Contributions: Conceptualization, A.A.; methodology, A.A.; software, M.B.A.; validation, A.A.; formal analysis, M.B.A.; investigation, M.J.; F.M.-A. and A.J.; resources, A.A. and R.A.; data curation, A.A.; writing — original draft preparation, A.A.; writing—review and editing, A.A. and A.J.; visualization, M.J.; supervision, A.A. and F.M.-A.; project administration, A.A.; funding acquisition, F.M.-A. All authors have read and agreed to the published version of the manuscript.

Funding: This research has been supported by the Ministry of Science, Innovation and Universities at the University of Almeria (Spain) under the program "Proyectos de I+D de Generacion de Conocimiento" of the national program for the generation of scientific and technological knowledge and strengthening of the R+D+I system with grant number PGC2018-098813-B-C33.

Institutional Review Board Statement: Not applicable.

Informed Consent Statement: Not applicable.

Data Availability Statement: Not applicable.

Acknowledgments: The authors would like to acknowledge the German Jordanian University, An Najah National University, and University of Almeria for facilitating this research.

Conflicts of Interest: The authors declare no conflict of interest. 


\section{References}

1. Yang, L.; Yan, H.; Lam, J.C. Thermal comfort and building energy consumption implications-A review. Appl. Energy 2014, 115, 164-173. [CrossRef]

2. Ministry of Energy and Mineral Resources (MEMR). Annual Report. 2019. Available online: http://www.memr.gov.jo (accessed on 3 February 2021).

3. National Electric Power Company (NEPCO). Annual Report. 2018. Available online: http://www.nepco.com.jo (accessed on 3 February 2021).

4. Ferreira, P.M.; Ruano, A.E.; Silva, S.; Conceicao, E.Z.E. Neural networks based predictive control for thermal comfort and energy savings in public buildings. Energy Build. 2012, 55, 238-251. [CrossRef]

5. Alfano, F.R.D.A.; Olesen, B.W.; Palella, B.I.; Riccio, G. Thermal comfort: Design and assessment for energy saving. Energy Build. 2014, 81, 326-336. [CrossRef]

6. Manzano-Agugliaro, F.; Montoya, F.G.; Sabio-Ortega, A.; García-Cruz, A. Review of bioclimatic architecture strategies for achieving thermal comfort. Renew. Sustain. Energy Rev. 2015, 49, 736-755. [CrossRef]

7. De Dear, R.; Brager, G.S. Developing an adaptive model of thermal comfort and preference. ASHRAE Tech. Data Bull. 1998, 14, 27-49.

8. Parsons, K. Human Thermal Environments: The Effects of Hot, Moderate, and Cold Environments on Human Health, Comfort, and Performance; CRC Press: Boca Raton, FL, USA, 2014.

9. Yun, G.Y. Influences of perceived control on thermal comfort and energy use in buildings. Energy Build. 2018, 158, 822-830. [CrossRef]

10. American Society of Heating, Refrigerating and Air-Conditioning Engineers (ASHRAE). Thermal Environmental Conditions for Human Occupancy; ANSI/ASHRAE Standard: Peachtree Corners, GA, USA, 2012; pp. 55-2020.

11. Directive (EU) 2018/844 of the European Parliament and of the Council of 30 May 2018 Amending Directive 2010/31/EU. Available online: https: / / eur-lex.europa.eu/legal-content/EN/TXT/?uri=uriserv:OJ.L_.2018.156.01.0075.01.ENG\&toc=OJ:L: 2018:156:FULL (accessed on 29 September 2020).

12. Moore, T.; Ridley, I.; Strengers, Y.; Maller, C.; Horne, R. Dwelling performance and adaptive summer comfort in low-income Australian households. Build. Res. Inf. 2017, 45, 443-456. [CrossRef]

13. Olesen, B.W. Indoor environmental input parameters for the design and assessment of energy performance of buildings. REHVA J. 2015, 52, 17-23.

14. Mendes, A.; Bonassi, S.; Aguiar, L.; Pereira, C.; Neves, P.; Silva, S.; Teixeira, J.P. Indoor air quality and thermal comfort in elderly care centers. Urban Clim. 2015, 14, 486-501. [CrossRef]

15. Van Hoof, J. Forty years of Fanger's model of thermal comfort: Comfort for all? Indoor Air 2008, 18, 182-201. [CrossRef]

16. d'Ambrosio Alfano, F.R.; Olesen, B.W.; Palella, B.I.; Pepe, D.; Riccio, G. Fifty years of PMV model: Reliability, implementation and design of software for its calculation. Atmosphere 2020, 11, 49. [CrossRef]

17. Nicol, J.F.; Humphreys, M.A. Adaptive thermal comfort and sustainable thermal standards for buildings. Energy Build. 2002, 34, 563-572. [CrossRef]

18. Wu, T.; Cao, B.; Zhu, Y. A field study on thermal comfort and air-conditioning energy use in an office building in Guangzhou. Energy Build. 2018, 168, 428-437. [CrossRef]

19. Mora, R.; Bean, R. Thermal comfort: Designing for people. ASHRAE J. 2018, 60, 40-46.

20. Newsham, G.R.; Birt, B.J.; Arsenault, C.; Thompson, A.J.; Veitch, J.A.; Mancini, S.; Burns, G.J. Do 'green'buildings have better indoor environments? New evidence. Build. Res. Inf. 2013, 41, 415-434. [CrossRef]

21. Guideline 10-2016-Interactions Affecting the Achievement of Acceptable Indoor Environments; American Society of Heating, Refrigerating and Air-Conditioning Engineers (ASHRAE): Atlanta, GA, USA, 2016.

22. Soebarto, V.; Bennetts, H. Thermal comfort and occupant responses during summer in a low to middle income housing development in South Australia. Build. Environ. 2014, 75, 19-29. [CrossRef]

23. De Dear, R.; Brager, G.S. Developing An Adaptive Model of Thermal Comfort and Preference; Indoor Environmental Quality (IEQ) SF-98-7-3 (4106) (RP-884); California Digital Library: Berkeley, CA, USA, 1998.

24. Nicol, F.; Humphreys, M. Derivation of the adaptive equations for thermal comfort in free-running buildings in European standard EN15251. Build. Environ. 2010, 45, 11-17. [CrossRef]

25. Ren, Z.; Chen, D. Modelling study of the impact of thermal comfort criteria on housing energy use in Australia. Appl. Energy 2018, 210, 152-166. [CrossRef]

26. Hwang, R.L.; Lin, T.P.; Kuo, N.J. Field experiments on thermal comfort in campus classrooms in Taiwan. Energy Build. 2016, 38, 53-62. [CrossRef]

27. Fanger, P.O. The effect of air humidity in buildings on man's comfort and health. In Proceedings of the CISCO-ITBTP Seminar Humidity in Building, Saint Remy les Chevreuse, France, November 1982.

28. Fanger, P.O.; Toftum, J. Extension of the PMV model to non-air-conditioned buildings in warm climates. Energy Build. 2002, 34, 533-536. [CrossRef]

29. Moujalled, B.; Cantin, R.; Guarracino, G. Comparison of thermal comfort algorithms in naturally ventilated office buildings. Energy Build. 2008, 40, 2215-2223. [CrossRef] 
30. Holopainen, R.; Tuomaala, P.; Hernandez, P.; Häkkinen, T.; Piira, K.; Piippo, J. Comfort assessment in the context of sustainable buildings: Comparison of simplified and detailed human thermal sensation methods. Build. Environ. 2014, 71, 60-70. [CrossRef]

31. Ji, W.; Cao, B.; Luo, M.; Zhu, Y. Influence of short-term thermal experience on thermal comfort evaluations: A climate chamber experiment. Build. Environ. 2017, 114, 246-256. [CrossRef]

32. Castaño-Rosa, R.; Rodríguez-Jiménez, C.E.; Rubio-Bellido, C. Adaptive thermal comfort potential in mediterranean office buildings: A case study of Torre Sevilla. Sustainability 2018, 10, 3091. [CrossRef]

33. WheaterOnline.co.uk. Jordan. Available online: https://www.weatheronline.co.uk/reports/climate/Jordan.htm. (accessed on 4 December 2020).

34. Thermal Environmental Conditions for Human Occupancy; American Society of Heating, Refrigerating and Air-Conditioning Engineers (ASHRAE): Atlanta, GA, USA, 2013.

35. Harvey, L.D.D. A Handbook on Low-Energy Buildings District-Energy Systems: Fundamentals, Techniques and Example; Routledge: London, UK, 2015.

36. De Dear, R. Developing an adaptive model of thermal comfort and preference, field studies of thermal comfort and adaptation. ASHRAE Tech. Data Bull. 1998, 104, 145-167. 